\title{
Suppression of prolactin and reduction of milk secretion by effect of cabergoline in lactating dairy ewes
}

\author{
G. Caja, (i) A. Elhadi, * (i) X. Such, (1) and A. A. K. Salama (1) \\ Group of Research in Ruminants (G2R), Department of Animal and Food Sciences, Universitat Autònoma de Barcelona, 08193 Bellaterra, \\ Barcelona, Spain
}

\begin{abstract}
The effects of cabergoline, an ergot derivative and dopamine receptor agonist, were investigated in 30 ewes of 2 dairy breeds (Manchega; MN, $\mathrm{n}=15$; Lacaune; LC, $\mathrm{n}=15$ ). Ewes were in a similar latelactation stage, but differed in milk yield according to breed (MN vs. LC, $1.02 \pm 0.03$ vs. $2.27 \pm 0.05 \mathrm{~kg} / \mathrm{d}$ ). Treatments consisted of a single intramuscular injection of cabergoline at different doses per ewe. Cabergoline doses (per ewe) were: low $(0.56 \mathrm{mg})$, high $(1.12$ $\mathrm{mg}$ ), and control (CON; $0 \mathrm{mg}$; $1 \mathrm{~mL}$ of saline). Milk yield was recorded daily ( $\mathrm{d}-14$ to 25$)$, milk and blood were sampled, and udder traits were measured from d -2 to 14 after injection. No local reaction at the injection site, nor behavior and metabolic indicators of the ewes were detected after the cabergoline injection, but milk yield fell rapidly in both breeds (MN vs. LC, $-54 \%$ vs. $-27 \%$ ) when compared with CON ewes. Cabergoline effects progressively disappeared after d 5, and no milk yield differences between treatments were detected from d 8 to 25 after injection. Milk fat and protein contents increased similarly $(22 \%$ and $23 \%$; respectively) in both breeds and at both cabergoline doses until d 5 , and the effects disappeared thereafter. Plasma prolactin (PRL) decreased dramatically in the low- and high-treated ewes the day after injection when compared with the CON ewes, and reached values below the detection limit of the assay between d 1 and 5 , increasing similarly thereafter. On d 14, PRL values were $58 \%$ greater in the low- and high-treated than in the CON ewes, showing that PRL concentrations rebounded when the cabergoline effects ceased. Total udder volume correlated with milk accumulated in the udder $(\mathrm{r}=0.77)$ of all groups of ewes throughout the experiment, suggesting its use as a noninvasive method for the estimation of milk stored in the udder. Udder volume was similar for the low and high ewes, but both
\end{abstract}

Received December 19, 2019.

Accepted July 23, 2020.

*Corresponding author: abdelaali.elhadi@uab.cat values were lower than those of the CON ewes from $\mathrm{d}$ 1 to 14 after injection. No other effects on udder size were detected. Cabergoline dramatically inhibited PRL secretion and decreased milk yield and udder volume of lactating dairy ewes. The low dose of cabergoline was as effective as the high dose in the 2 breeds of dairy ewes. These results suggest the use of cabergoline to facilitate the decrease of milk production in dairy ewes (e.g., dry-off, illness care), although further research in pregnant dairy ewes and during the following lactation is still needed.

Key words: ergotic, dairy sheep, milk secretion, prolactin, udder

\section{INTRODUCTION}

Late pregnancy and drying-off are challenging periods for dairy ruminants. Pregnant ewes are susceptible to ketone bodies toxemia and new intramammary infections (IMI) because of the increase of glucose demand and the decrease of immunocompetence (Shwimmer et al., 2008; Fthenakis et al., 2012; Zhao et al., 2019). The risks are greater in high-yielding and twin-bearing ewes (Oddy and Holst, 1991; Silva-del-Río et al., 2010), especially when using low energy diets or feed restriction during drying-off (Caldeira et al., 2007). Additionally, nutrient restriction at dry-off decreases basal blood prolactin (PRL) by $30 \%$ in dairy cows fed hay on the days preceding the dry-off, as reported by Ollier et al. (2013).

Nutrient restriction at dry-off decreases the proliferation of mononuclear cells and compromises immunocompetence (Ollier et al., 2014, 2015; Zhao et al., 2019). Cessation of milking results in udder engorgement, which leads mammary gland epithelium to apoptosis and, if excessive, induces mammary inflammation and cell necrosis (Zobel et al., 2015). In dairy sheep, where abrupt drying-off is commonly done, selective (i.e., IMI positive) or generalized antibiotic therapy is recommended at drying-off to improve udder health and milk yield in the following lactation (Gonzalo et al., 2004; Linage and Gonzalo, 2008). Consequently, reduction 
of udder insults during dry-off may be a strategy to decrease the use of antibiotic therapies at drying-off.

Under a physiological approach, an interesting method to facilitate the dry-off could be inducing the cessation of milk production by interfering with the transmission of hormonal signals from the pituitary gland (i.e., PRL inhibition). This approach has been proposed as a management tool in dairy husbandry (Lacasse et al., 2019) to avoid inappropriate lactation or to alleviate the nutritional stress in sick or injured lactating animals unable to support their level of production.

Dopamine has a direct effect on the lactotrophs of the anterior pituitary by binding to their $\mathrm{D}_{2}$ receptors and reducing PRL exocytosis and gene expression (Fitzgerald and Dinan, 2008). Ergotic (e.g., bromocriptine, cabergoline, and metergoline) and nonergotic (e.g., quinagolide) derivatives also bind to $\mathrm{D}_{2}$ receptors of the lactotrophs and have shown to decrease PRL secretion and milk production, although with differences in affinity, half-life, and side effects (Bole-Feysot et al., 1998; Barlier and Jaquet 2006; Kvernmo et al., 2006). The use of PRL inhibitors in lactating ruminants has been deeply reviewed by Lacasse et al. (2012, 2016, 2019) and Zhao et al. (2019).

Quinagolide injection proved to reduce plasmatic PRL and to be effective for milk reduction, both in early- (Lacasse et al., 2011; Boutinaud et al., 2012) and late-lactation (Ollier et al., 2013, 2014, 2015) dairy cows. Moreover, proliferation and survival of mammary epithelial cells after quinagolide treatment were fully restored by PRL injection (Lollivier et al., 2015; Lacasse et al., 2016), supporting the galactopoietic role of PRL in ruminants.

Cabergoline is a highly specific agonist of $\mathrm{D}_{2}$ receptors with a long elimination half-life (Kvernmo et al., 2006; Odaka et al., 2014). The use of cabergoline, initially authorized by the European Medicines Agency (EMA, 2015) for facilitating the dry-off of cattle, decreased plasma PRL and accelerated udder involution (reducing the secretory activity of mammary epithelial cells), udder engorgement, and incidence of milk leakage in dairy cows (Bach et al., 2015; Boutinaud et al., 2016). A large-scale clinical study with 900 dairy cows in 63 farms (Hop et al., 2019) reported that, under practical conditions, cabergoline decreases the risks of milk leakage and of new IMI during the drying-off and postcalving periods. Nevertheless, despite the positive effects of cabergoline without food-safety risks for consumers when withdrawal period is respected (i.e., $32 \mathrm{~d}$ during dry-off or 8 milkings during lactation; EMA, 2015), its use in high-yielding dairy cows at late pregnancy has been associated with occasional adverse events, usually within $24 \mathrm{~h}$ of injection. These negative effects in- clude recumbency and mortality, which were related to metabolic disorders (i.e., hypocalcemia, hypothermia, ataxia, adipsia, circulatory disorder, and diarrhea). Therefore, the marketing authorization of cabergoline as Velactis (Ceva Animal Health, Libourne, France) first suspended (EMA, 2016), and finally banned, its use in Europe (EMA, 2019), considering that the overall benefit-risk balance in dairy cows was negative.

Few and controversial data are available on the use of dopamine agonists in small ruminants. Arlt et al. (2011) reported the inefficacy of cabergoline to cease inappropriate lactations in hobby goats. On the other hand, Lacasse et al. (2016) cited no effects on milk production of repeated injections of quinagolide $(1 \mathrm{mg} / \mathrm{d}$ for $4 \mathrm{wk}$ ), whereas a single cabergoline injection [1 $\mathrm{mg}$; V. Lollivier (McGill University, Montreal, Canada) and M. Boutinaud (INRAe Agrocampus Ouest, Rennes, France), unpublished results] decreased milk yield $(-28 \%)$ in dairy goats. The effects of dopamine agonists and the adequate dose for dairy ewes are unknown. The objective of this work was to study the effects of 2 doses of cabergoline on PRL suppression and milk secretion to determine the suitable dose and the time-lasting effects in 2 breeds of dairy ewes in late lactation.

\section{MATERIALS AND METHODS}

The study was conducted in the experimental farm of the Servei de Granges i Camps Experimentals (SGCE) of the Universitat Autònoma de Barcelona (UAB), in Bellaterra (Barcelona, Spain) during 2016. Animalcare conditions and management practices agreed with the Spanish Royal Decree 53/2013 on the protection of animals used for experimental purposes, the codes of recommendations for the welfare of dairy sheep of the Ministry of Agriculture, Alimentation and Environment of Spain (MAPA, 2007), and the procedures stated by the Ethical Committee of Animal and Human Experimentation of the UAB (Procedure \#4992).

\section{Ewe Management and Feeding}

A total of 30 ewes of 2 dairy breeds (Manchega; MN, $\mathrm{n}=15$; Lacaune; $\mathbf{L C}, \mathrm{n}=15)$ in late lactation (185 \pm 11 and $186 \pm 11$ DIM, respectively; values are means $\pm \mathrm{SE}$ ) were used in this experiment. They were kept as a single group on wood-chip bedded pens. Their main characteristics (MN and LC, respectively) were: age $(3.8 \pm 0.5$ and $2.7 \pm 0.4 \mathrm{yr})$, BW $(73.6 \pm 2.5$ and 67.6 $\pm 1.9 \mathrm{~kg})$, BCS $(3.08 \pm 0.07$ and $2.85 \pm 0.07)$, and milk yield $(1.02 \pm 0.03$ and $2.27 \pm 0.05 \mathrm{~kg} / \mathrm{d})$. All ewes wore ruminal mini-boluses for electronic identification (20 g; Datamars, Bedano, Switzerland) that were used for automatic milk recording (Ait-Saidi et al., 2014). 
Machine milking was conducted twice daily (0700 and $1700 \mathrm{~h}$ ) in a $2 \times 12$ parallel-stall milking parlor with automatic milk-recording devices (MM25SG; DeLaval, Tumba, Sweden) with similar procedures to those described by Elhadi et al. (2019).

Diet consisted of a TMR ad libitum (forage: concentrate $=55: 45 \%$; DM basis) with alfalfa hay as forage and a farm-produced concentrate [ingredients: soybean hulls, $50.0 \%$; barley grain, $10.0 \%$; oats grain, $10.0 \%$; gluten feed meal, $10.0 \%$; rapeseed 00 meal, $5.0 \%$; soybean oil, $5.0 \%$; corn grain, $4.0 \%$; bi-calcium phosphate, $2.5 \%$; cane molasses, $2.0 \%$; VitafacOvino-0.3 premix (DSM Nutritional Products, Madrid, ES), $1.0 \%$; salt, $0.5 \%$; as fed]. Additionally, all ewes received $100 \mathrm{~g}$ of whole-grain corn in the individual feeders of the milking parlor at each milking to encourage coming inside. Nutrient requirements were calculated by INRAtion v.4.07 (Educagri éditions, Dijon, France). Ewes had free access to water and commercial mineral blocks (Multi-Block; Agrària Comarcal del Vallès, Llerona, Spain) in the pens.

\section{Experimental Treatments}

Ewes were blocked in 3 balanced groups of 10 animals (5 of each breed) according to age, BW, BCS, and milk yield, and submitted to a short-term lactation experiment divided in 2 periods: pre- $(\mathrm{d}-14$ to -1$)$ and post-injection (d 0 to 25). The experimental design consisted of a $2 \times 3$ factorial (breed $\times$ treatment) to which the ewe groups were randomly allocated. Treatments consisted of the dose of cabergoline (Velactis $1.12 \mathrm{mg} / \mathrm{mL}$ of cabergoline; Ceva Animal Health) intramuscularly injected into the middle of the left side of the neck after the evening milking, and were: low (0.56 mg of cabergoline/ewe), high (1.12 mg of cabergoline/ewe), and control (CON, $1 \mathrm{~mL}$ of saline/ewe). The cabergoline doses were achieved by the injection of 0.5 or $1.0 \mathrm{~mL}$ of Velactis per ewe, similar to the EMA (2015) recommended treatment dose $($ RTD = $5.6 \mathrm{mg} / \mathrm{cow}$ or 7 to $10 \mu \mathrm{g} / \mathrm{kg}$ of $\mathrm{BW}$ ), equivalent to 0.49 to $0.70 \mathrm{mg}$ of cabergoline for a standard ewe of $70 \mathrm{~kg}$ of BW. These doses were far from the $3 \times$ RTD (1.47-2.10 mg/ewe) and $5 \times$ RTD (2.45-3.50 mg/ewe) overdoses injected for the target animal-safety studies (EMA, 2015). Although the cabergoline diluent used in the Velactis product was a lipidic solvent mixture (i.e., dimethyl sulfoxide and medium-chain triglycerides), we used sterile saline solution $(0.9 \% \mathrm{NaCl}$; Laboratorios Grifols, Parets del Valles, Spain) in our CON ewes to evaluate the whole local reaction to the commercial product injection. Collected milk was discarded during the following week according to the withdrawal recommendations.

\section{Measurements, Sampling, and Analyses}

Reactions to the Injection. Local tolerance to cabergoline was evaluated on d 0,1 , and 7 after injection using a severity score (0-3 points), according to the diameter of the adverse reaction produced by the injection $(0=$ none; $1=$ smaller than $2 \mathrm{~cm} ; 2=$ between $2-8 \mathrm{~cm} ; 3=$ larger than $8 \mathrm{~cm}$; accuracy, 0.5 points). Special surveillance of the treated ewes was done at 8-h intervals by a technician supervised by the veterinarian responsible for the SGCE of the UAB during the $48 \mathrm{~h}$ following injection. General appearance, eating and drinking behavior, and mobility of the ewes when attending the twice-daily milking were monitored throughout the experiment.

Milk Yield. Milk yield of individual ewes was recorded by weight at each milking during the whole experimental period ( $\mathrm{d}-14$ to 25 ), using the milk-flow and milk-recording automatic units of the milking parlor (MM25SG, DeLaval). Data were uploaded using the AlPro software 7.2 (DeLaval) and reviewed daily to avoid incorrect values.

Milk Composition. Representative milk samples of each ewe were taken pre- $(\mathrm{d}-2$ and -1$)$ and post- (d 1 , $2,5,7$, and 14) cabergoline injection for compositional analysis using proportional milk samplers (DeLaval). Milk samples $(50 \mathrm{~mL})$ were composited according to the daily milking intervals (morning:evening, 60:40), preserved with an antimicrobial tablet (Bronopol; Broad Spectrum Micro-tabs II, D and F Control Systems, San Ramon, CA), and stored at $4^{\circ} \mathrm{C}$ until analysis. Milk samples were analyzed in the Dairy Herd Improvement Laboratory of Catalonia (ALLIC, Cabrils, Spain) for fat, total protein, lactose, urea (Milkoscan FT2; Foss, Hillerød, Denmark), and SCC (Fossomatic 5000, Foss).

Udder Size. Udder measurements were recorded before the evening milking on $\mathrm{d}-2$ and -1 pretreatment, and d 2, 5, 7, and 14 posttreatment, according to the agreed-upon FAO-M4 study protocol for dairy sheep (Labussière, 1983), with the ewes restrained by head-lockers in the milking stalls. Udder volume was estimated by water displacement using a 5 -L bucket of warm water. Udder width was measured as the maximum udder width value by using a surgical thickness compass (Hauptner, Solingen, Germany), and udder base-floor distance was taken by a measuring flexible tape, both from the back of the ewes.

Blood Measurements. Blood samples were taken from the jugular vein using 4-mL Vacutainer tubes with EDTA K2E 7.2 mg (BD; Belliver Industrial Estate, Plymouth, UK) $1 \mathrm{~h}$ after the morning milking (without corn supplement) and before feeding at $\mathrm{d}-1$ (pretreatment), and $\mathrm{d} 1,2,5,7$, and 14 (posttreatment). The EDTA blood-collecting tubes were used to avoid pos- 
sible interactions in the hormonal enzymatic competitive analyses (Kohek et al., 2002). Plasma was obtained by blood centrifugation for $15 \mathrm{~min}$ at $2,000 \times g$ at $4^{\circ} \mathrm{C}$, transferred to 0.5-mL Eppendorf tubes (Hamburg, Germany), and stored at $-20^{\circ} \mathrm{C}$ for analysis.

Concentration of PRL in plasma was measured by ELISA sandwich-type analysis (human PRL-ELISA KAPD1291, DIAsource Immunoassays, Leuven, Belgium), and the stopped ELISA plates were read in an automatic reader (iEMS Reader MF V.2.9-0; Labsystems España, Barcelona, Spain) at $450 \mathrm{~nm}$. Detection limit, intra- and interassay coefficients of variation were $0.35 \mathrm{ng} / \mathrm{mL}, 5.5$, and $6.5 \%$, respectively.

Effect of cabergoline treatments on the metabolic status of the ewes was assessed by the plasmatic concentrations of glucose, lactate, $\gamma$-glutamyl transferase (GGT), phosphorus, and creatinine, using an Olympus AU480 analyzer (Olympus Europa, Hamburg, Germany) with the specific Reagent System of Olympus (OSR, Beckman Coulter, Krefeld, Germany); the respective analytical methods and reagents used were: hexokinase method (OSR6121), lactate oxidase method (OSR6193), $\gamma$-glutamyl-3-carboxy-4-nitroanilide method (OSR6119, with a concentration greater than $4 \mathrm{mmol} / \mathrm{L}$ ), phospho molybdate method (OSR6122), and the Jaffé method (OSR6178). Changes in absorbance were read at 340 $\mathrm{nm}$, except for creatinine, which were read at $520 \mathrm{~nm}$. Nonesterified fatty acids (NEFA) were determined by enzymatic colorimetry [ACS-ACOD-MEHA; acyl-CoA synthetase, acyl-CoA oxidase, 3-methyl-N-ethyl-N( $\beta$ hydroxy-ethyl) aniline] in the same analyzer using NEFA HR reagents (Fujifilm Wako Chemicals, Neuss, Germany) and read at $410 \mathrm{~nm}$. Additionally, concentration of lactose in plasma was used as an indicator of the leakiness of the lactocyte tight junctions. This was analyzed by difference based on 2 enzymatic reactions using galactose dehydrogenase and $\beta$-galactosidase, one measuring galactose and the other lactose and galactose (Boehringer Mannheim/R-Biopharm, Darmstad, Germany) in the Olympus AU480 analyzer and at 340 $\mathrm{nm}$. The use of EDTA-collecting tubes did not allow the analyses of $\mathrm{Ca}, \mathrm{K}$, and $\mathrm{Na}$ in plasma.

\section{Statistical Analyses}

Data were analyzed by the MIXED procedure for repeated measurements of SAS v.9.4 (SAS Institute Inc., Cary, NC). The statistical mixed model used to evaluate the similarity of the ewe's groups during the pretreatment period and the response to the treatments contained the fixed effects of breed (MN and LC), cabergoline dose (L, H and $\mathrm{CO}$ ), sampling time, and breed $\times$ treatment interaction, as well as the random effects of the experimental unit (the animal), and the residual error. Values of the variables were computed for their respective treatment and sampling dates, the means expressed as least squares means, and separated by pairwise comparison using the PDIFF ADJUST = SCHEFFE test of SAS. Pearson correlation coefficients (r) were calculated using the CORR procedure of SAS. Significance was declared at $P<0.05$, and a tendency was considered when $P<0.10$.

\section{RESULTS AND DISCUSSION}

\section{Cabergoline Dosage}

According to the mean BW of the dairy ewes enrolled in the experiment (MN and LC, average of 73.6 and $67.6 \mathrm{~kg}$ of $\mathrm{BW}$, respectively), the chosen cabergoline doses (low and high, respectively) were slightly lower in the MN (7.6 and $15.2 \mu \mathrm{g} / \mathrm{kg}$ of BW) than in the LC (8.3 and $16.6 \mu \mathrm{g} / \mathrm{kg}$ of BW) ewes. The low dose fell in the range of the EMA (2015) recommended treatment dose of cabergoline (RTD $=7-10 \mu \mathrm{g} / \mathrm{kg}$ of BW) and agreed with the dosage previously used for the dry-off of dairy cows (Boutinaud et al., 2016;8.7 $\mu \mathrm{g} / \mathrm{kg}$ of $\mathrm{BW})$. On the other hand, the high dose doubled the RTD but was far from the $3 \times$ RTD $(21-30 \mu \mathrm{g} / \mathrm{kg}$ of BW) and $5 \times$ RTD $(35-50 \mu \mathrm{g} / \mathrm{kg}$ of BW) overdoses injected for target animal-safety studies (EMA, 2015). As previously indicated by Lacasse et al. (2016, 2019), and despite the inconsistency of some studies done in goats, a dose of $1.0 \mathrm{mg}$ of cabergoline (approximately $16.6 \mu \mathrm{g} / \mathrm{kg}$ of BW for a $60 \mathrm{~kg}$ of BW goat) was also used in high-yielding dairy goats (i.e., $3.5 \mathrm{~kg} / \mathrm{d}$ of milk) in early lactation.

\section{Reaction to Cabergoline Injection}

Intramuscular injection of cabergoline at both low and high doses did not produce local or adverse reactions in the right site of the ewes' necks; only $3 \mathrm{MN}$ ewes, 1 from each treatment (i.e., CON, low, and high), showed a slight swelling reaction (score 1) from the injection. No swelling reactions were observed in the LC ewes, characterized by having open fleeces and wool-uncovered necks, in comparison to $\mathrm{MN}$, which may have allowed a more precise and cleaner intramuscular injection. As a consequence, the values of swelling scores were very low and similar between treatments $(0.10 \pm 0.11$, on average) .

Regardless of the cabergoline dose used, no general reactions or apparent changes in the behavior of the low- and high- treated ewes (i.e., abatement, recumbency, lack of interest to the feed bunk or drinkers after 
feed offering) were detected during the 48-h following injection and throughout the experiment, when compared with the CON ewes. Moreover, no changes in the motion of the ewes, when being moved for the twicedaily milking or in their eating behavior in the milking parlor (i.e., refusal of whole-grain corn), were recorded. Unfortunately, no data on local or adverse side effects of the high dose of cabergoline used in the goat experiments were available for comparison (Lacasse et al., 2016, 2019).

\section{Prolactin in Plasma}

As shown in Figure 1, plasma concentrations of PRL in the CON ewes ranged between 12 and $24 \mathrm{ng} / \mathrm{mL}$ $(17.8 \pm 1.5 \mathrm{ng} / \mathrm{mL}$, on average) from $\mathrm{d}-1$ to 14 ; no differences were detected in either breed $(P=0.99)$. On the contrary, concentrations of PRL dramatically fell in the cabergoline-treated ewes (Figure 1), with values that were under the detection limit (i.e., 0.35 $\mathrm{ng} / \mathrm{mL}$ ) during $\mathrm{d} 1$ and 2 after injection, slightly increased values on $\mathrm{d} 5$, and higher values thereafter. The low PRL values persisted for both low and high doses from d 1 to 5 ( $-86 \%$, on average; $P<0.001$; Table 1) and increased after d 7 (Figure 1) when compared with CON ewes, with no differences between breeds $(P=0.89$; Table 1$)$. Values of plasmatic PRL of our CON ewes $1 \mathrm{~h}$ after milking agreed with the basal values reported by Boutinaud et al. (2016) in Holstein dairy cows before milking (approximately $16 \mathrm{ng} / \mathrm{mL}$ ). Nevertheless, the effect of cabergoline injection on the PRL concentration of our lactating ewes was greater than the decrease reported by Boutinaud et al. (2016; $-39 \%)$ in Holstein dairy cows at dry-off when compared with conventionally dried cows, both fed a dry hay diet. This lower PRL difference may have been a consequence of the negative effect of feed restriction in the CON cows, as previously reported by Ollier et al. (2013). Additionally, the difference between control and cabergoline-injected cows in the Boutinaud et al. (2016) study persisted for $8 \mathrm{~d}$ and disappeared on d 14, similar to what we observed in our ewes (Figure 1). Moreover, $-20 \%$ plasma PRL after cabergoline injection was reported in the Bach et al. (2015) study, but the authors did not mention the cow's BW and the blood sampling time with regard to milking, precluding the comparison with other data. Lacasse et al. (2011) and Boutinaud et al. (2012) also reported decreases in the concentrations of PRL released at milking ( -12 to $-32 \%$ ) in dairy cows treated with repeated injections of quinagolide during lactation (8 wk).

Interestingly, greater PRL values in plasma were detected on d 14 after injection in the low and high ewes (58\%, on average; $P<0.001$ ), when compared with the CON ewes, indicating a PRL rebound effect after ceasing the cabergoline treatment (Figure 1). The PRL rebound was the response (paradoxical reaction) of the ewe's metabolism to return to its basal state (homeostasis) after having been modified by the injection of cabergoline. Evidence of PRL rebound can also be observed in the results of Ollier et al. (2013) in dairy cows injected with quinagolide for $4 \mathrm{~d}$ before dry-off (approximately $50 \%$ increase basal value at d 14 after injection), but it was not visible in the Bach et al. (2015) and Boutinaud et al. (2016) dairy cows injected with cabergoline at dry-off.

Given that cabergoline half-life in cows is $19 \mathrm{~h}$ (EMA, 2015 ), and due to its high affinity for dopamine $\mathrm{D}_{2}$-like receptors (Kvernmo et al., 2006), the occurrence of the PRL rebound on d 14 after injection may be related to a midterm feedback of pituitary's lactotrophs, decreasing the release of natural dopamine, which will result in a rise of PRL. Mechanism of PRL rebound in rats after dopamine withdrawal was explained by Chen et al. (1993) and Chang and Shin (1999), who demonstrated that dopamine acts on $\mathrm{D}_{2}$ receptors both to inhibit and to stimulate PRL release. We hypothesize that this may be related to the decrease of the activity of tyrosine hydroxylase (TH), the rate-limiting key enzyme in the biosynthesis and availability of catecholamines (i.e., dopamine, noradrenaline, and adrenaline) during the cabergoline treatment. Gordon et al. (2008) showed that TH binds to dopamine in high- and low-affinity binding sites, and dissociation of $\mathrm{TH}$ from dopamine markedly increases TH activity that will lead to greater PRL concentration in blood.

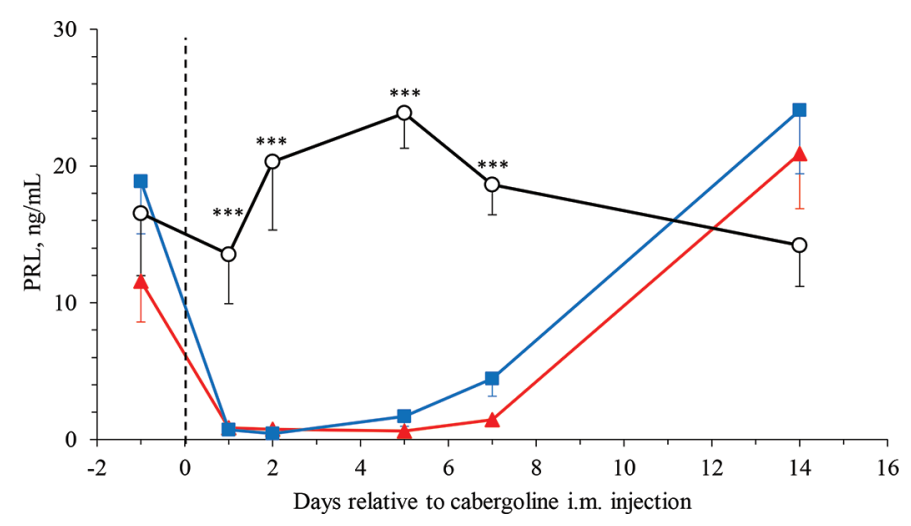

Figure 1. Effects of a single injection of cabergoline at different doses on plasma prolactin (PRL) of lactating Manchega and Lacaune dairy ewes. Doses of cabergoline: $\boldsymbol{\Delta}$ (high, $1.12 \mathrm{mg} ; \mathrm{n}=10$ ), $\mathbf{\square}$ (low, $0.56 \mathrm{mg} ; \mathrm{n}=10)$, and $\bigcirc($ control, $0 \mathrm{mg} ; \mathrm{n}=10)$. Values are LSM of both breeds averaged, with the SEM indicated by vertical bars. Differences between control and cabergoline i.m. injected ewes were significant from d 1 to 7 (***, $P<0.001)$. 
Caja et al.: CABERGOLINE IN DAIRY EWES

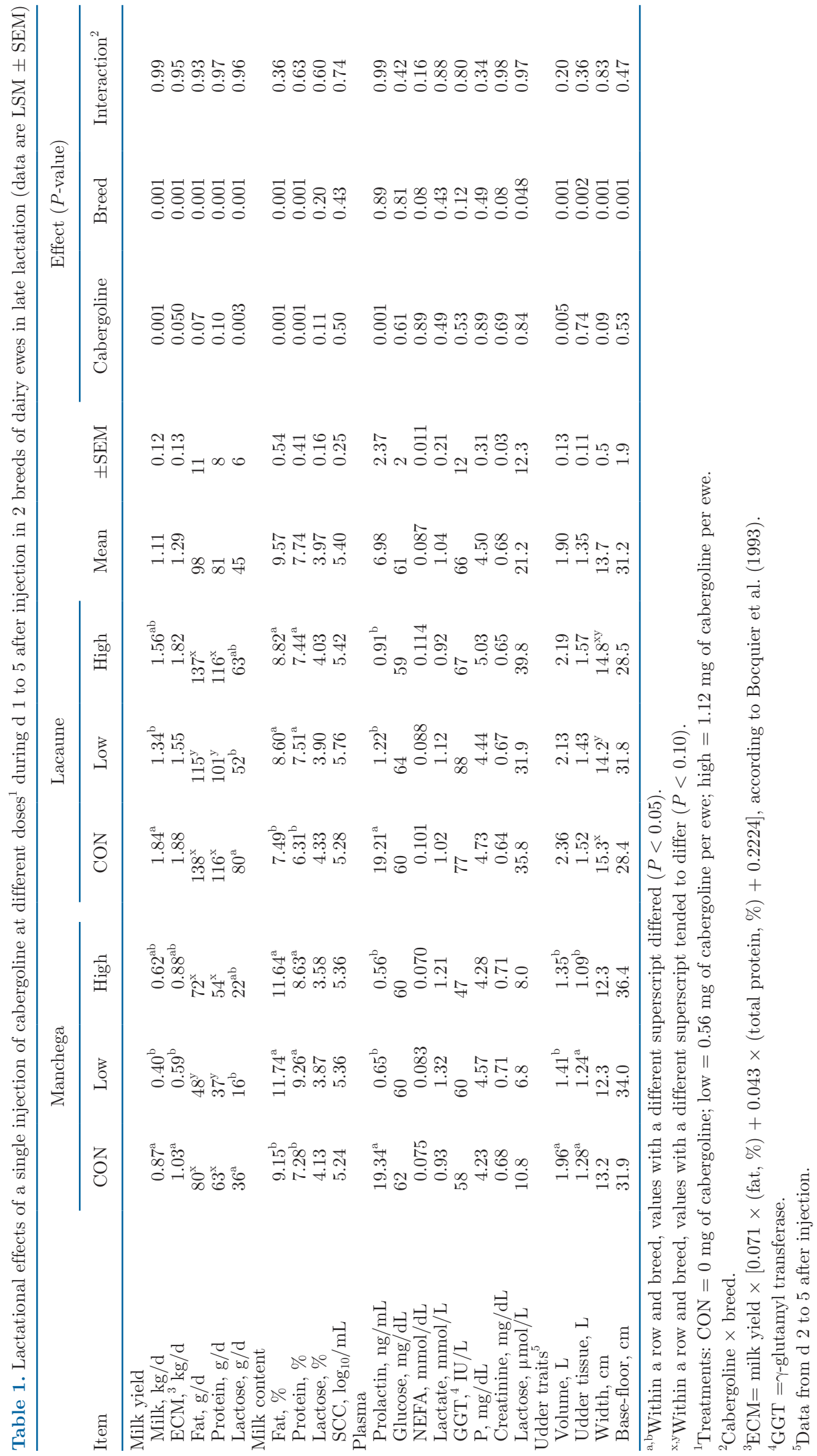




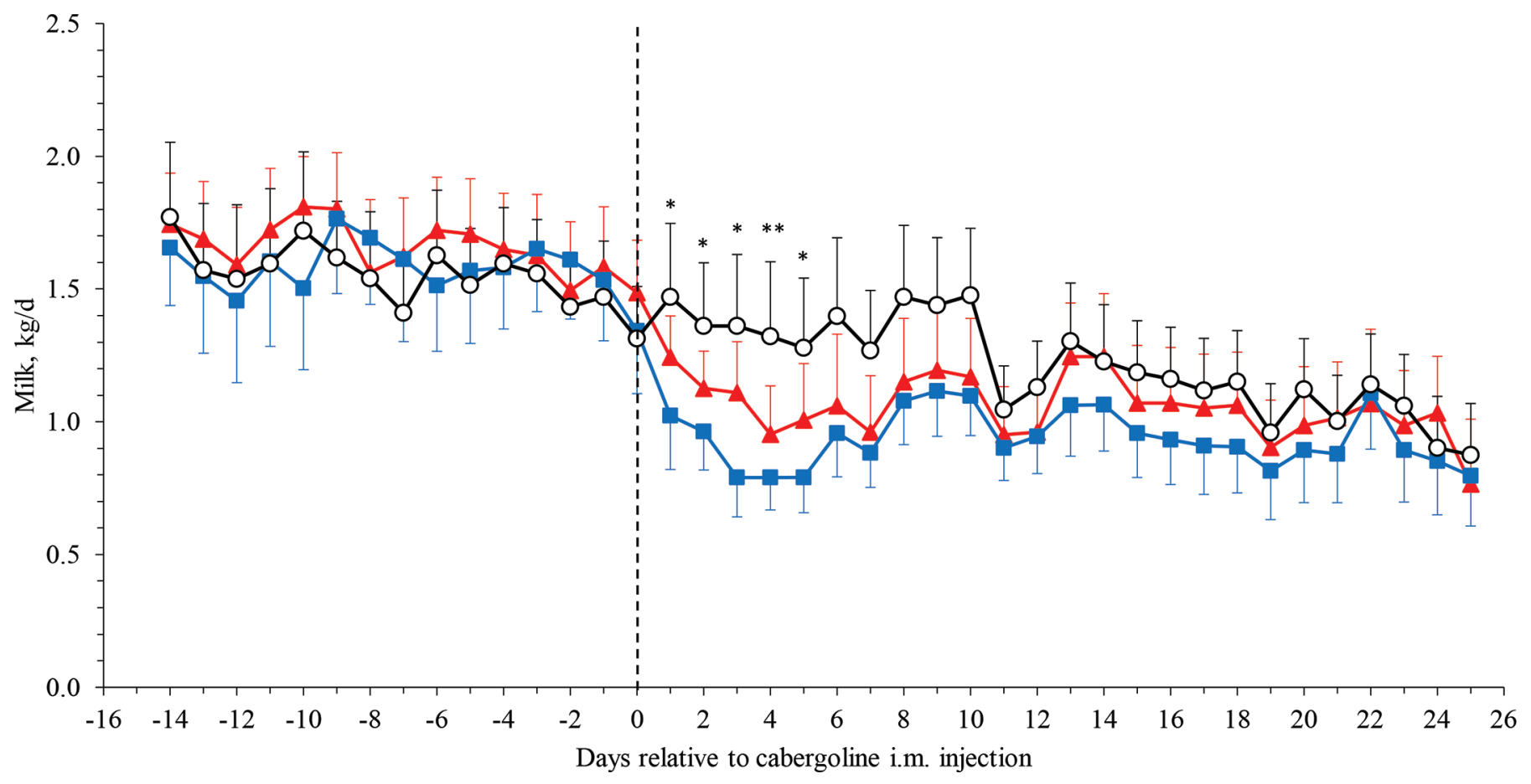

Figure 2. Effects of a single injection of cabergoline at different doses on milk yield of lactating Manchega and Lacaune dairy ewes. Doses of cabergoline: $\boldsymbol{\Delta}$ (high, $1.12 \mathrm{mg} ; \mathrm{n}=10$ ), $\mathbf{\square}$ (low, $0.56 \mathrm{mg} ; \mathrm{n}=10$ ), and $\bigcirc$ (control, $0 \mathrm{mg} ; \mathrm{n}=10$ ). Values are LSM of both breeds averaged, with the SEM indicated by vertical bars. Differences between control and cabergoline i.m. injected ewes tended or were significant from d 1 to $5(* P<0.05 ; * * P<0.01)$.

\section{Milk Yield}

All of the ewes were healthy at the start of the experiment and showed high milk yields for late lactation before applying the treatments (Figure 2). Lactation persistency, estimated as the linear slope of the milk yield curve according to the stage of lactation was -18 $\mathrm{g} / \mathrm{d}$ for the CON ewes $(\mathrm{y}=-0.0178 \mathrm{x}+1.44 ; \mathrm{r}=0.92$, $P<0.001)$ during the whole experiment $(\mathrm{d}-14$ to $25)$, with differences in both breeds. Persistency was inverse to the level of production of each breed (MN, $-6 \mathrm{~g} / \mathrm{d} ; \mathrm{LC},-28 \mathrm{~g} / \mathrm{d} ; P=0.004)$ : the lower the yield, the higher the persistency.

Milk yield fell rapidly during the first $5 \mathrm{~d}$ after treatment (Figure 2 and Table 1) for both cabergoline doses (low vs. high, $-40 \%$ vs. $-22 \% ; P<0.001$ ) and ewe breeds (MN and LC, $-54 \%$ and $-27 \% ; P<0.001$ ) when compared with $\mathrm{CON}$ ewes. No differences were detected between the low and high doses in either breed (Table 1), and the cabergoline $\times$ breed interaction was not significant $(P=0.99)$. On average, the injection of cabergoline produced a sudden and marked decrease of milk yield $(-31 \% ; P<0.001)$ immediately after the treatment, and the slope (d 1 to 5 ) of the milk regression was $-64 \mathrm{~g} / \mathrm{d}$ of milk, on average. Milk yield progressively increased after $\mathrm{d} 5$, and no differences were detected between the $\mathrm{CON}$ and the cabergoline-treated ewes on d 8 after injection $(P=0.23)$ and thereafter (d 9 to $25 ; P=0.49$ ). Nevertheless, all ewes showed an unexpected increase in milk yield between d 8 to 10 (26\% on average), followed by a milk drop on d 11 and $12(-20 \%$, on average; Figure 2), without differences between the CON and the cabergoline-treated ewes $(P$ $=0.90)$. As a result, the persistency of the cabergolinetreated ewes throughout the whole experiment $(\mathrm{d}-14$ to 25$)$ was on average $-23 \mathrm{~g} / \mathrm{d}(\mathrm{y}=-0.0233 \mathrm{x}+1.35$; $\mathrm{r}=0.85, P<0.001)$, similar to the $\mathrm{CON}$ ewes $(P=$ $0.35)$, and without differences between the high and low doses $(P=0.85)$. Again, persistency was inverse to the yield of each breed $(\mathrm{MN},-16 \mathrm{~g} / \mathrm{d} ; \mathrm{LC},-30 \mathrm{~g} / \mathrm{d} ; P$ $=0.026$ ).

Milk yield also declines faster in quinagolide-treated cows (daily injections for $8 \mathrm{wk}$ ) during lactation than in control cows (Lacasse et al., 2011; approximately $-15 \%$ ), but no effects of a single injection of cabergoline have been tested during lactation. Milk decrease after the cabergoline injection in our ewes duplicated the above indicated value in dairy cows. The increase in milk yield after d 11 was unlikely produced by the PRL rebound because the parallel raise in milk yield of the CON ewes and the numerically greater concentration of PRL in the plasma of the low ewes (Figure 1). 


\section{Milk Composition}

On average, milk fat (Figure 3a) and milk protein (Figure $3 \mathrm{~b}$ ) of our ewes increased rapidly from d 1 to 5 (22 and $23 \%$, respectively; $P<0.001)$ after the cabergoline treatment. Despite these increases in milk component concentrations, daily yields of milk fat and milk protein tended to decrease $(P=0.07$ and $P=$ 0.10 , respectively; Table 1 ) as a result of the decrease in milk yield produced by the cabergoline injection. The effects on milk fat and protein disappeared after $\mathrm{d} 7$ after injection, accompanying the recovery of milk yield previously discussed after $\mathrm{d} 5$. On the contrary, no differences in milk lactose content were detected between treatments on average $(P=0.11)$, although the content of lactose in the milk of the cabergoline-treated ewes was lower than in the CON ewes on $\mathrm{d} 2$ and 5 (Figure 3c; $P=0.042$ ). Milk lactose yield decreased by effect of cabergoline (Table $1 ; P=0.003$ ), although no differences were detected between the low and high ewes. The differences in milk composition among treatments decreased after d 5 , and no differences in the concentration of milk components were detected at d 7 and 14 after injection.

Despite the reported drop in milk yield of quinagolidetreated cows during lactation (Lacasse et al., 2011), only numerically greater milk fat and milk protein contents are seen in milk; nevertheless, daily yields of both milk fat and milk protein decrease, agreeing with the results obtained in our ewes. Moreover, marked decreases of milk lactose content during the last $4 \mathrm{wk}$ of treatment and of lactose yield were reported by Lacasse et al. (2011) in the quinagolide-treated cows, agreeing with our results in cabergoline-treated ewes during lactation. Conversely, Boutinaud et al. (2016) did not find effects on the composition of mammary secretions (i.e., fat, protein, and lactose) of Holstein cows treated with cabergoline at dry-off, although the composition of mammary secretions after ceasing milking is not directly comparable to that of milk obtained at milking during lactation.

No effects of cabergoline treatment were detected on the SCC of our ewes $(P=0.50$; Table 1$)$ that, despite being in late lactation, showed a low SCC (5.40 \pm 0.26 , on average, equivalent to 250,000 cells $/ \mathrm{mL}$ ). All effects of cabergoline on milk composition of our ewes disappeared after the first week posttreatment, and no differences with the CON ewes were detectable at d 14 .

\section{Metabolic Indicators}

Effect of cabergoline treatments on the metabolic status of the ewes was assessed by the plasmatic concentrations of several metabolic indicators during the critical period posttreatment (d 1 to 5 ), as well as for glucose and creatinine during the whole experiment (data not shown). No effects of cabergoline treatment were detected on glucose, NEFA, lactate, and the GGT

a)

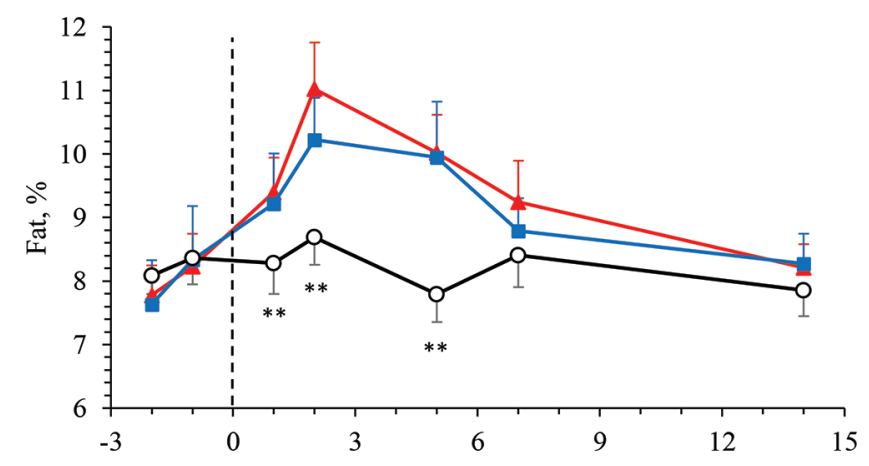

b)

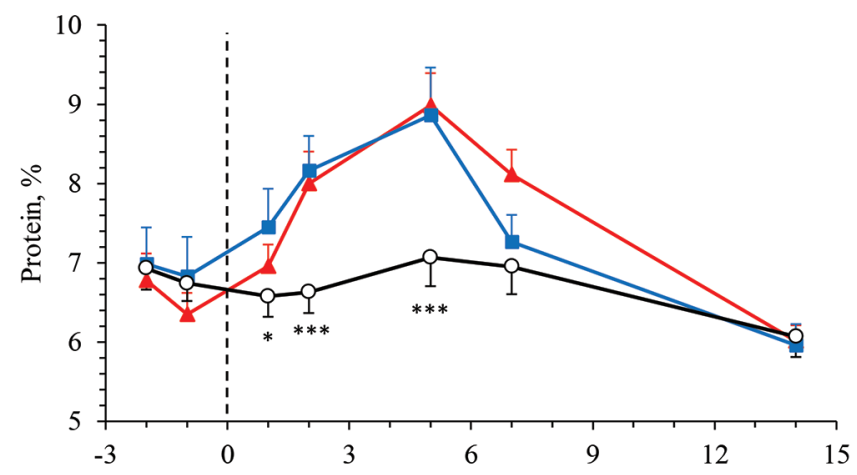

c)

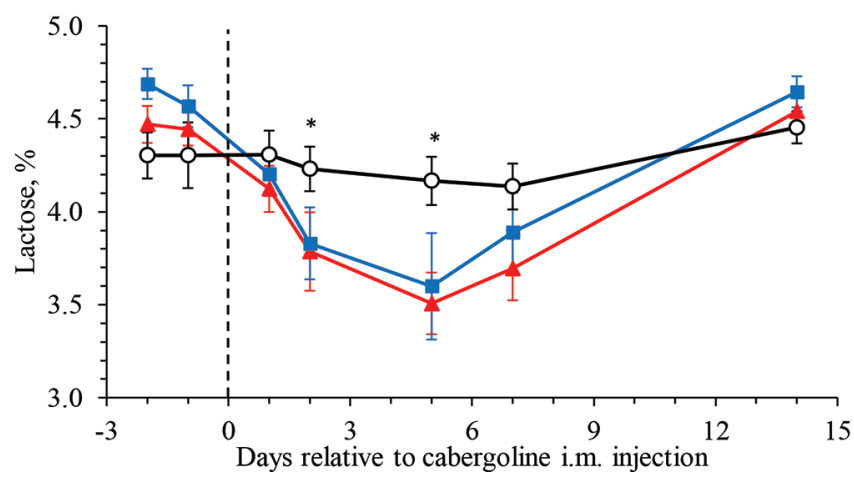

Figure 3. Effects of a single injection of cabergoline at different doses on milk composition (panel $\mathrm{a}=$ fat; $\mathrm{b}=$ protein; $\mathrm{c}=$ lactose) of lactating Manchega and Lacaune dairy ewes. Doses of cabergoline: $\boldsymbol{\Delta}$ (high, $1.12 \mathrm{mg} ; \mathrm{n}=10$ ), $\mathbf{\text { 口 }}$ (low, $0.56 \mathrm{mg} ; \mathrm{n}=10$ ), and $\bigcirc$ (control, 0 $\mathrm{mg} ; \mathrm{n}=10)$. Values are LSM of both breeds averaged, with the SEM indicated by vertical bars. Differences in fat and protein milk contents between control and cabergoline i.m. injected ewes were significant from d 1 to $5\left({ }^{*} P<0.05 ;{ }^{* *} P<0.01 ;{ }^{* * *} P<0.001\right)$. Differences in lactose milk content were significant at $\mathrm{d} 2$ and $5\left({ }^{*} P<0.05\right)$. 
liver enzyme (related to glutathione metabolism, AA absorption, and protection against oxidation), as shown in Table 1. Moreover, glucose and creatinine in plasma were steady throughout the whole experimental period $(P=0.97)$. Plasmatic values of NEFA tended to be greater in the LC ewes according to their greater milk production $(P=0.08$; Table 1$)$, but did not differ by cabergoline treatment $(P=0.89)$, indicating that cabergoline did not produce metabolic stress in our ewes. Similar results were obtained by Ollier et al. (2014) in quinagolide-treated dairy cows during drying-off.

Although it was not possible to analyze $\mathrm{Ca}$ and $\mathrm{Mg}$ values because of the EDTA-collecting blood tubes, no differences in $\mathrm{P}$ plasmatic values were detected (4.50 $\pm 0.31 \mathrm{mg} \mathrm{P} / \mathrm{dL}$, on average) between treatments $(P$ $=0.89)$ or breeds $(P=0.49)$. According to Venjakob et al. (2017), there are positive associations between serum $\mathrm{Ca}$ and $\mathrm{P}$ concentrations in dairy cows, suggesting that no differences in blood Ca should be expected as a result of the cabergoline injection in our ewes. Lacasse et al. (2019) concluded that lowering the PRL concentration is unlikely to be responsible for a reduction in blood $\mathrm{Ca}$ and hypocalcemia, as was suspected in the cabergoline-banning decision of EMA $(2016,2019)$. Nevertheless, it should be stressed that the use of cabergoline is still suspended for cattle in the European Union.

No differences in plasma lactose were detected by effect of the cabergoline treatment in our ewes $(P=0.84$; Table 1), although marked differences were observed according to breed $(P=0.048)$, with the LC having greater values than MN ewes. This result agrees with previous data in the same breeds and with the fact that LC ewes have greater milk yield and are more tolerant to milk accumulation between milkings than the MN ewes (Castillo et al., 2008). Consequently, no tight junction disruption (leakiness) was produced in our ewes, despite their level of production, as a result of the injection of cabergoline. Milk lactose yield reduction in our cabergoline-treated ewes (Table 1) could be explained by the reduction of lactose synthesis in the mammary epithelial cells, and not by leaking through cellular tight junctions.

\section{Udder Traits}

Involution of the udder induced by the cabergoline treatment was assessed by the changes in its anatomical measurements. The greater the reduction of the udder size, the better the effectivity of the dry-off facilitation treatment was. Udder size will be an objective noninvasive criterion to monitor the involution of the udder during the dry-off. Data of the udder volume (range, 1.00-3.42 L) and the corresponding milk yield obtained at the afternoon milking (range, $0.07-1.41 \mathrm{~kg}$ ) of our ewes throughout the experiment ( $\mathrm{d}-2$ to 14 ) correlated $(\mathrm{y}=0.4034 \mathrm{x}-0.226 ; \mathrm{r}=0.77, P<0.01 ;$ Figure 4$)$ and explained more than one-half $(59 \%)$ of the variation of milk accumulated in the udder. Udder volume differed between breeds in our ewes (MN, $1.57 \pm 0.07$; LC, 2.23 $\pm 0.07 ; P<0.001)$, agreeing with their differences in milk yield. Additionally, the volume of the udder tissue (nonmilk volume of the udder) estimated by difference also correlated with the total volume of the udder $(\mathrm{r}=$ $0.82, P<0.001)$; the udder tissue of the LC ewes was $26 \%$ greater than in the MN ewes $(P=0.002)$, as previously reported by Rovai et al. (2008). In a prospective study on the milkability of different dairy breeds in the Mediterranean, Labussière (1983) reported positive correlations between udder volume and daily milk yield $(\mathrm{r}=0.40-0.71)$, although the reported correlations vary with the age of the ewes and the milk fraction considered, as also indicated by Fernández et al. (1983) in Manchega dairy ewes $(\mathrm{r}=0.17-0.85)$. Similarly, udder width $(\mathrm{MN}, 12.6 \pm 0.3 ; \mathrm{LC}, 14.8 \pm 0.3 ; P<0.001)$ and base-floor distance $(\mathrm{MN}, 34.1 \pm 1.1$; LC, $28.3 \pm$ 1.1; $P<0.001)$ also were, on average, different between breeds in our ewes: the greater the yield, the greater the size of the udder.

With regard to the cabergoline treatments, volume and width of the udder (Figure 5) were similar for the ewes treated with the low and high doses of cabergoline ( $P=0.36$ and $P=0.56$, respectively) but, on average,

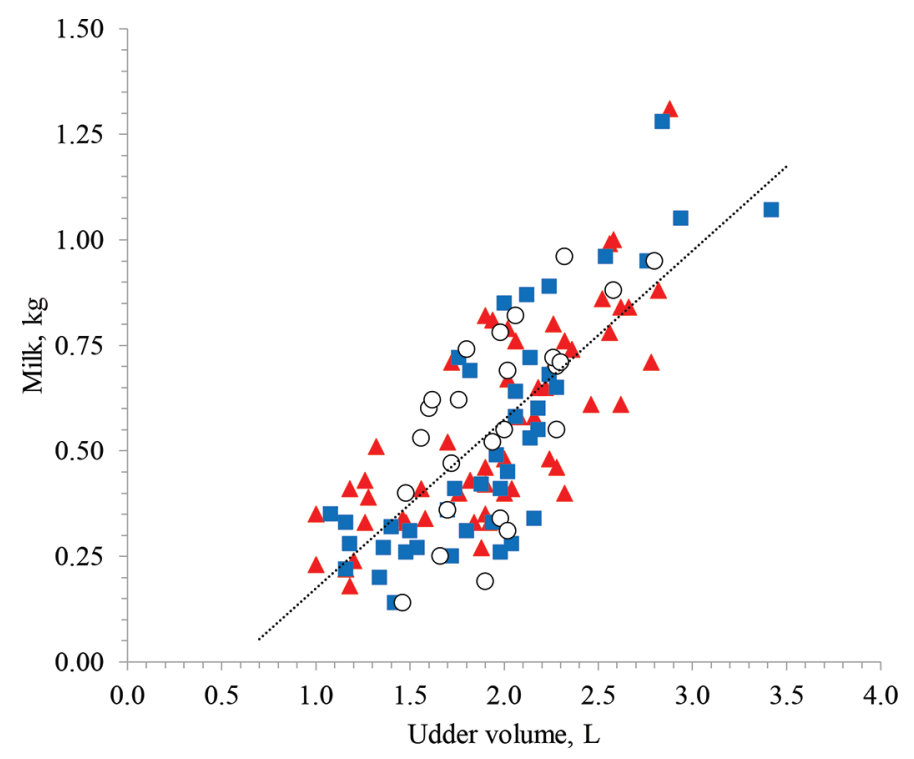

Figure 4. Correlation $(\mathrm{y}=0.4034 \mathrm{x}-0.226 ; \mathrm{r}=0.77, P<0.01 ; \mathrm{n}$ $=180)$ between udder volume and milk yield at afternoon milking of lactating Manchega and Lacaune dairy ewes after a single injection of cabergoline at different doses. Doses of cabergoline: $\boldsymbol{\Delta}$ (high, $1.12 \mathrm{mg}$; $\mathrm{n}=60, \mathrm{r}=0.77 ; P<0.05)$, $\boldsymbol{\square}$ (low, $0.56 \mathrm{mg} ; \mathrm{n}=60, \mathrm{r}=0.83 ; P<$ $0.05)$, and $\bigcirc$ (control, $0 \mathrm{mg} ; \mathrm{n}=60, \mathrm{r}=0.66 ; P<0.05)$. 
udder volume was lower $(-18 \% ; P<0.005)$ and udder width tended to be lower $(-6 \% ; P=0.09)$ than those of the CON ewes from d 2 to 5 (Table 1 ). Nevertheless, no differences in udder volume between treatments were detected in the LC ewes $(P=0.57)$. Interestingly, despite not having differences in milk yield between $\mathrm{CON}$ and both low and high treatments at d 14 after injection, udder volume of the cabergoline-treated ewes remained smaller than in the CON ewes (Figure 5a). This result may be the consequence of a reduction of the secretory tissue of the udder (i.e., mammary gland involution), which was only observed in the case of the treated MN ewes $(P=0.045)$, but that did not affect milk yield in the late stage of lactation of our ewes. There is also the possibility of a side-effect of the PRL rebound on oxytocin secreted at milking, agreeing with the oxytocin-PRL positive feedback suggested by Ken-

a)

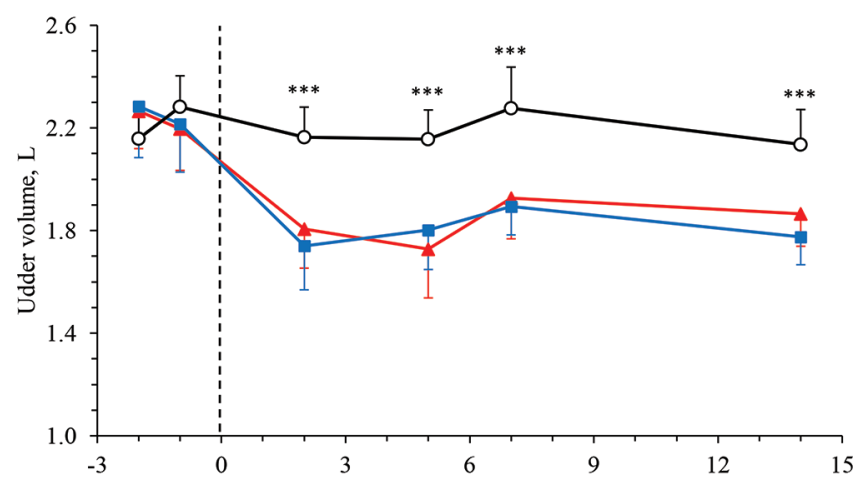

b)

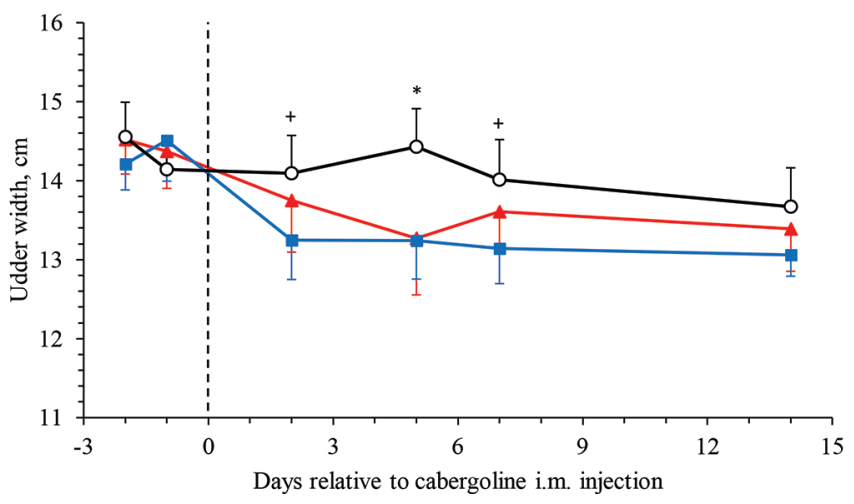

Figure 5. Effects of a single injection of cabergoline at different doses on the udder traits (panel $\mathrm{a}=$ volume; $\mathrm{b}=$ width) of lactating Manchega and Lacaune dairy ewes. Doses of cabergoline: $\boldsymbol{\Delta}$ (high, 1.12 $\mathrm{mg} ; \mathrm{n}=10)$, $\mathbf{\square}$ (low, $0.56 \mathrm{mg} ; \mathrm{n}=10)$, and $\bigcirc($ control, $0 \mathrm{mg} ; \mathrm{n}=10)$. Values are LSM of both breeds averaged, with the SEM indicated by vertical bars. Differences between control and cabergoline i.m. injected ewes were significant from d 2 to $14(* * * P<0.001)$ in udder volume, and were significant at d $5\left({ }^{*} P<0.05\right)$ or tended to decrease $(+P<$ $0.10)$ at $d 2$ and 7 in udder width. nett and McKee (2012) in rats, which may have reduced the amount of residual milk in the cabergoline-treated ewes. This last hypothesis needs further research. No effects of treatments were detected on the base-floor distance of the udder of either breed of ewes $(P=0.53$; Table 1), indicating that premilking udder volume and, to a lesser extent, the premilking udder width were the only useful morphological traits to assess udder involution.

\section{CONCLUSIONS}

Cabergoline temporarily inhibited PRL and markedly decreased milk secretion and udder volume, but increased most milk components in lactating dairy ewes. The effect disappeared after $5 \mathrm{~d}$, and milk yield and milk composition did not differ from $\mathrm{CON}$ values when milking was maintained for more than $20 \mathrm{~d}$ after injection. The effect on udder volume lasted longer than the effect on milk yield, which may be related to the PRL rebound after cessation of cabergoline treatment, and needs further research. The low dose was as effective as the high dose of cabergoline for the reduction of lactation, without differences between them with regard to udder traits. Overall, the use of $0.56 \mathrm{mg} /$ ewe of cabergoline as a dry-off facilitator may be a strategy of interest in high-yielding dairy ewes to reduce feed-restriction stress (i.e., ketosis risk) and antibiotic therapy at dry-off. No apparent adverse reactions were detected, and our data do not support the suspicion that use of cabergoline, at the RTD, may be related to hypocalcemia or mammary epithelial cell tight junctions disruption in lactating dairy ewes. Additionally, the results of this study may be useful to understand the use of PRL inhibitors as a management tool in dairy small ruminants. Further research on the use of cabergoline on pregnant dairy ewes at the dry-off and during the following lactation is needed. Finally, it should be stressed that the use of cabergoline is currently suspended in the European Union for cattle, and that its use in dairy sheep will require a specific approval by EMA.

\section{ACKNOWLEDGMENTS}

This study was partially funded by Ceva Animal Health (Libourne, France; contract UAB-2016/ CF613827). The authors are grateful to Alessio Valenza and Ana I. de Prado-Taranilla (Ceva Animal Health, Libourne, France) and Alex Martino and Juan-Pedro Casas (Ceva Salud Animal, Barcelona, Spain) for their advice and support. Thanks are also extended to Ramón Costa and the technical team of the SGCE (Servei de Granges i Camps Experimentals) of the Universitat 
Autònoma de Barcelona (Bellaterra, Barcelona, Spain) for the care of the animals, and to Charles (Chuck) Simmons (Cerdanyola, Barcelona, Spain) for the English language and style revision of the manuscript. The authors have not stated any conflicts of interest.

\section{REFERENCES}

Ait-Saidi, A., G. Caja, A. A. K. Salama, and S. Carné. 2014. Implementing electronic identification for performance recording in sheep: I. Manual versus semiautomatic and automatic recording systems in dairy and meat farms. J. Dairy Sci. 97:7505-7514. https://doi.org/10.3168/jds.2014-8090.

Arlt, S., A. Reinecke, M. Drillich, C. Fischer-Tenhagen, and W. Heuwieser. 2011. [Inappropriate lactation syndrome in goats-case collection and experiences with mastectomy] [Article in German]. Tierarztl. Prax. Ausg. G. Grosstiere Nutztiere 39:27-32.

Bach, A., A. De-Prado, and A. Aris. 2015. The effects of cabergoline administration at dry-off of lactating cows on udder engorgement, milk leakages, and lying behavior. J. Dairy Sci. 98:7097-7101. https://doi.org/10.3168/jds.2015-9751.

Barlier, A., and P. Jaquet. 2006. Quinagolide: A valuable treatment option for hyperprolactinaemia. Eur. J. Endocrinol. 154:187-195. https://doi.org/10.1530/eje.1.02075.

Bocquier, F., F. Barillet, P. Guillouet, and M. Jacquin. 1993. Prévision de l'énergie du lait de brebis à partir de différents résultats d'analyses : Proposition de lait standard pour les brebis laitières. Ann. Zootech. 42:57-66. https://doi.org/10.1051/animres: 19930106

Bole-Feysot, C., V. Goffin, M. Edery, N. Binart, and P. A. Kelly. 1998. Prolactin (PRL) and its receptor: Actions, signal transduction pathways and phenotypes observed in PRL receptor knockout mice. Endocr. Rev. 19:225-268. https://doi.org/10.1210/edrv.19.3 .0334 .

Boutinaud, M., N. Isaka, V. Lollivier, F. Dessauge, E. Gandemer, P. Lamberton, A. I. De Prado Taranilla, A. Deflandre, and L. M. Sordillo. 2016. Cabergoline inhibits prolactin secretion and accelerates involution in dairy cows after dry-off. J. Dairy Sci. 99:5707-5718. https://doi.org/10.3168/jds.2015-10782.

Boutinaud, M., V. Lollivier, L. Finot, R. M. Bruckmaier, and P. Lacasse. 2012. Mammary cell activity and turnover in dairy cows treated with the prolactin-release inhibitor quinagolide and milked once daily. J. Dairy Sci. 95:177-187. https://doi.org/10.3168/jds .2011-4461 http://dx.doi.org/doi:10.3168/jds.2011-4461.

Caldeira, R. M., A. T. Belo, C. C. Santos, M. I. Vazques, and A. V. Portugal. 2007. The effect of long-term feed restriction and over-nutrition on body condition score, blood metabolites and hormonal profiles in ewes. Small Rumin. Res. 68:242-255. https://doi .org/10.1016/j.smallrumres.2005.08.026.

Castillo, V., X. Such, G. Caja, R. Casals, E. Albanell, and A. A. K. Salama. 2008. Effect of milking interval on milk secretion and mammary tight junction permeability in dairy ewes. J. Dairy Sci. 91:2610-2619. https://doi.org/10.3168/jds.2007-0916.

Chang, A., and S. H. Shin. 1999. Dopamine agonists both stimulate and inhibit prolactin release in GH4ZR7 cells. Eur. J. Endocrinol. 141:387-395. https://doi.org/10.1530/eje.0.1410387.

Chen, C., J. Zhang, J. M. Israel, I. J. Clarke, and J. D. Vincent. 1993. Mechanism of the prolactin rebound after dopamine withdrawal in rat pituitary cells. Am. J. Physiol. 265:E145-E152. https://doi .org/10.1152/ajpendo.1993.265.1.E145.

Elhadi, A., A. A. K. Salama, X. Such, E. Albanell, P. G. Toral, G. Hervás, P. Frutos, and G. Caja. 2019. Effects of shearing 2 breeds of dairy ewes during lactation under mild winter conditions. J. Dairy Sci. 102:1712-1724. https://doi.org/10.3168/jds.2018-15380.

EMA (European Medicines Agency). 2015. CVMP (Committee for Medical Products for Veterinary Use) assessment report for Velactis (EMEA/V/C/003739/0000). Accessed Mar. 15, 2020. https: //www.ema.europa.eu/en/documents/assessment-report/velactis -epar-public-assessment-report_en.pdf.
EMA (European Medicines Agency). 2016. EMA recommends suspending the veterinary medicine Velactis used in dairy cows at the time of drying off. Accessed Mar. 15, 2020. https://www .ema.europa.eu/en/news/ema-recommends-suspending-veterinary -medicine-velactis-used-dairy-cows-time-drying.

EMA (European Medicines Agency). 2019. Velactis, cabergoline. Accessed Mar. 15, 2020. https://www.ema.europa.eu/en/medicines/ veterinary/summaries-opinion/velactis.

Fernández, N., J. Arranz, G. Caja, A. Torres, and L. Gallego. 1983. [Milkability of Manchega breed dairy ewes: II. Milk production, fraction partitioning and milk emission kinetics]. Pages 667-686 in III Symposium Internacional de Ordeño Mecánico de Pequeños Rumiantes. Comité Español ed., Sever Cuesta, Valladolid, Spain.

Fitzgerald, P., and T. G. Dinan. 2008. Prolactin and dopamine: What is the connection? A review article. J. Psychopharmacol. 22(2 suppl):12-19. https://doi.org/10.1177/0269216307087148.

Fthenakis, G. C., G. Arsenos, C. Brozos, I. A. Fragkou, N. D. Giadinis, I. Giannenas, V. S. Mavrogiannia, E. Papadopoulos, and I. Valasi. 2012. Health management of ewes during pregnancy. Anim. Reprod. Sci. 130:198-212. https://doi.org/10.1016/j.anireprosci.2012 .01 .016 .

Gonzalo, C., J. A. Tardáguila, L. F. De La Fuente, and F. San Primitivo. 2004. Effects of selective and complete dry therapy on prevalence of intramammary infection and on milk yield in the subsequent lactation in dairy ewes. J. Dairy Res. 71:33-38. https://doi .org/10.1017/S0022029903006526.

Gordon, S. L., N. S. Quinsey, P. R. Dunkley, and P. W. Dickson. 2008. Tyrosine hydroxylase activity is regulated by two distinct dopamine-binding sites. J. Neurochem. 106:1614-1623. https://doi .org/10.1111/j.1471-4159.2008.05509.x.

Hop, G. E., A. I. de Prado-Taranilla, N. Isaka, M. Ocak, J. Bertet, K. Supré, A. Velthuis, Y. H. Schukken, and A. Deflandre. 2019. Efficacy of cabergoline in a double-blind randomized clinical trial on milk leakage reduction at drying-off and new intramammary infections across the dry period and postcalving. J. Dairy Sci. 102:11670-11680. https://doi.org/10.3168/jds.2019-16281.

Kennett, J. E., and D. T. McKee. 2012. Oxytocin: An emerging regulator of prolactin secretion in the female rat. J. Neuroendocrinol. 24:403-412. https://doi.org/10.1111/j.1365-2826.2011.02263.x.

Kohek, M., C. R. M. Leme, I. T. Nakamura, S. A. de Oliveira, V. Lando, and B. B. Mendonca. 2002. Effects of EDTA and sodium citrate on hormone measurements by fluorometric (FIA) and immunofluorometric (IFMA) methods. BMC Clin. Pathol. 2:2. https: //doi.org/10.1186/1472-6890-2-2.

Kvernmo, T., S. Hartter, and E. Burger. 2006. A review of the receptor-binding and pharmacokinetic properties of dopamine agonists. Clin. Ther. 28:1065-1078. https://doi.org/10.1016/j.clinthera.2006 .08 .004 .

Labussière, J. 1983. [Project M4 FAO: Study of dairy performances and milkability of several dairy sheep breeds of the Mediterranean basin]. Pages 730-792 in III Symposium Internacional de Ordeño Mecánico de Pequeños Rumiantes. Comité Español ed., Sever Cuesta, Valladolid, Spain. [Article in French].

Lacasse, P., V. Lollivier, R. M. Bruckmaier, Y. R. Boisclair, G. F. Wagner, and M. Boutinaud. 2011. Effect of the prolactin-release inhibitor quinagolide on lactating dairy cows. J. Dairy Sci. 94:1302-1309. https://doi.org/10.3168/jds.2010-3649.

Lacasse, P., V. Lollivier, F. Dessauge, R. M. Bruckmaier, S. Ollier, and M. Boutinaud. 2012. New developments on the galactopoietic role of prolactin in dairy ruminants. Domest. Anim. Endocrinol. 43:154-160. https://doi.org/10.1016/j.domaniend.2011.12.007.

Lacasse, P., S. Ollier, V. Lollivier, and M. Boutinaud. 2016. New insights into the importance of prolactin in dairy ruminants. J. Dairy Sci. 99:864-874. https://doi.org/10.3168/jds.2015-10035.

Lacasse, P., X. Zhao, N. Vanacker, and M. Boutinaud. 2019. Review: Inhibition of prolactin as a management tool in dairy husbandry. Animal 13(S1):s35-s41. https://doi.org/10.1017/S1751731118003312.

Linage, B., and C. Gonzalo. 2008. Influence of an intramammary infusion at drying-off of combined penethamate hydriodide, benethamine penicillin, and framycetin sulfate on intramammary 
infections and somatic cell counts in dairy sheep. J. Dairy Sci. 91:3459-3466. https://doi.org/10.3168/jds.2007-0842.

Lollivier, V., P. Lacasse, J. Angulo Arizala, P. Lamberton, S. Wiart, J. Portanguen, R. Bruckmaier, and M. Boutinaud. 2015. In vivo inhibition followed by exogenous supplementation demonstrates galactopoetic effects of prolactin on mammary tissue and milk production in dairy cows. J. Dairy Sci. 98:8775-8787. https://doi .org/10.3168/jds.2015-9853.

MAPA. 2007. Ministerio de Agricultura, Pesca y Alimentación. Guías de prácticas correctas de higiene: Ovino de leche. $2^{\mathrm{a}}$ edición 2007. Accessed Dec. 7, 2019. http://www.mapama.gob.es/es/ganaderia/ publicaciones/CCAE_tcm30-105306.pdf.

Odaka, H., T. Numakawa, N. Adachi, Y. Ooshima, S. Nakajima, Y. Katanuma, T. Inoue, and H. Kunugi. 2014. Cabergoline, dopamine D2 receptor agonist, prevents neuronal cell death under oxidative stress via reducing excitotoxicity. PLoS One 9:e99271. https://doi .org/10.1371/journal.pone.0099271.

Oddy, K. H., and P. J. Holst. 1991. Maternal-foetal adaptation to mid pregnancy feed restriction in single-bearing ewes. Aust. J. Agric. Res. 42:969-978. https://doi.org/10.1071/AR9910969.

Ollier, S., X. Zhao, and P. Lacasse. 2013. Effect of prolactin-release inhibition on milk production and mammary gland involution at drying-off in cows. J. Dairy Sci. 96:335-343. https://doi.org/10 $.3168 /$ jds.2012-5955.

Ollier, S., X. Zhao, and P. Lacasse. 2014. Effects of feed restriction and prolactin-release inhibition at drying off on metabolism and mammary gland involution in cows. J. Dairy Sci. 97:4942-4954. https:/ /doi.org/10.3168/jds.2014-7914.

Ollier, S., X. Zhao, and P. Lacasse. 2015. Effects of feed restriction and prolactin-release inhibition at drying-off on susceptibility to new intramammary infection in cows. J. Dairy Sci. 98:221-228. https:/ /doi.org/10.3168/jds.2014-8426.
Rovai, M., G. Caja, and X. Such. 2008. Evaluation of udder cisterns and effects on milk yield of dairy ewes. J. Dairy Sci. 91:4622-4629. https://doi.org/10.3168/jds.2008-1298.

Shwimmer, A., G. Kenigswald, M. Van Straten, Y. Lavi, U. Merin, L. Weisblit, and G. Leitner. 2008. Dry-off treatment of Assaf sheep: Efficacy as a management tool for improving milk quantity and quality. Small Rumin. Res. 74:45-51. https://doi.org/10.1016/j .smallrumres.2007.03.003.

Silva-del-Río, N., P. M. Fricke, and R. R. Grummer. 2010. Effects of twin pregnancy and dry period feeding strategy on milk production, energy balance, and metabolic profiles in dairy cows. J. Anim. Sci. 88:1048-1060. https://doi.org/10.2527/jas.2009-2206.

Venjakob, P. L., S. Borchardt, and W. Heuwieser. 2017. Hypocalcemia - Cow-level prevalence and preventive strategies in German dairy herds. J. Dairy Sci. 100:9258-9266. https://doi.org/10.3168/ jds.2016-12494.

Zhao, X., B. Ponchon, S. Lanctôt, and P. Lacasse. 2019. Invited review: Accelerating mammary gland involution after drying-off in dairy cattle. J. Dairy Sci. 102:6701-6717. https://doi.org/10.3168/ jds.2019-16377.

Zobel, G., D. M. Weary, K. E. Leslie, and M. A. G. von Keyserlingk. 2015. Invited review: Cessation of lactation: Effects on animal welfare. J. Dairy Sci. 98:8263-8277. https://doi.org/10.3168/jds.2015 -9617 .

\section{ORCIDS}

G. Caja (๑) https://orcid.org/0000-0001-8606-3587

A. Elhadi $\odot$ https://orcid.org/0000-0003-4354-7105

X. Such (1) https://orcid.org/0000-0002-9712-4477

A. A. K. Salama @ https://orcid.org/0000-0003-2065-9702 